\title{
The Dilemma of Dual Renin-Angiotensin System Blockade in Chronic Kidney Disease: Why Beneficial in Animal Experiments But Not in the Clinic?
}

\section{V. ČERTÍKOVÁ CHÁBOVÁ ${ }^{1}$, L. ČERVENKA ${ }^{2,3}$}

${ }^{1}$ Department of Nephrology, First Faculty of Medicine, Charles University, Prague, Czech Republic, ${ }^{2}$ Center for Experimental Medicine, Institute for Clinical and Experimental Medicine, Prague, Czech Republic, ${ }^{3}$ Department of Pathophysiology, Second Faculty of Medicine, Charles University, Prague, Czech Republic

Received February 2, 2017

Accepted February 10, 2017

\section{Summary}

Drugs interfering with the renin-angiotensin-aldosterone system (RAAS) improved the prognosis in patients with hypertension, heart failure, diabetes and chronic kidney disease. However, combining different drugs brought no further benefit while increasing the risk of hyperkalemia, hypotension and acute renal failure. This was so with combining angiotensin converting enzyme inhibitors (ACEi) and angiotensin II receptors type 1 antagonists (ARB). Dissimilarly, in animal disease models this dual therapy proved clearly superior to single drug treatment and became the optimal standard regime for comparison with other treatments. This review analyzes the causes of the discrepancy of effects of the dual therapy between animal experiments versus clinical studies, and is focused on the outcomes in chronic kidney disease. Discussed is the role of species differences in RAAS, of the variability of the disease features in humans versus relative stability in animals, of the genetic uniformity in the animals but not in humans, and of the biased publication habits of experimental versus clinical studies. We attempt to understand the causes and reconcile the discordant findings and suggest to what extent dual RAAS inhibition should be continued in animal experiments and why its application in the clinics should be limited to strictly selected groups of patients.

\section{Key words}

Renin-angiotensin system - Angiotensin converting enzyme inhibitors - Angiotensin II type 1 receptor antagonists • Hypertension • Chronic kidney diseases

\section{Corresponding author}

L. Červenka, Center for Experimental Medicine, Institute for Clinical and Experimental Medicine, Prague, Czech Republic. E-mail: luce@ikem.cz

\section{Introduction}

"The individual on the operating table had systolic blood pressure of about $190 \mathrm{~mm} \mathrm{Hg}$ when anesthesia was induced. One of the kidneys was removed several minutes ago. Now the other kidney's poles are cut off. After a short compression to achieve hemostasis, the abdominal cavity is closed. The creature is allowed to recover and on the next day is alive and well."

(By an anonymous observer)

The individual mentioned above is a rat: a human treated in a similar way would have very little chance to survive and the involved medical staff to escape prosecution and imprisonment. Not surprisingly, humans and rats are different in many aspects, so the common sense says they will also respond differently to drugs or their combinations. There is robust evidence that suppression of renin-angiotensin-aldosterone system (RAAS) is beneficial in many human diseases, such as hypertension, heart failure, diabetes and chronic kidney disease (Bakris 2010, Bavishi et al. 2016, Braunwald 2015, Catalá-López et al. 2016, Chaugai et al. 2016, Cice et al. 2010, Cohn et al. 2001, Osborne et al. 2017, Palmer et al. 
2015, Pena-Planco et al. 2016, Ptinopolou et al. 2013, Remuzzi et al. 2002, Ruster and Wolf 2006, Sakata et al. 2015, Turner et al. 2012, Van Vark et al. 2012, Vejakama et al. 2002). It was reasoned that combination of different groups of drugs interfering with RAAS function on different levels would have additive or even multiplied effects. Combination of ACE inhibitors (ACEi) and angiotensin II receptor type 1 blockers (ARB) appeared one of the most promising. However, this combination failed to improve survival or event-free time in human trials; on the other hand, adverse effects were more frequent (Fried et al. 2008, Mia et al. 2011, Onuigbo 2009, Parving et al. 2012, Yusuf and ONTARGET Investigators 2008b, Rutkowski and Tylicky 2015). Conversely, in most animal experiments not only that it has been undoubtedly proved that the inappropriate activation of the intrarenal RAAS is the major culprit of the progression of chronic kidney disease, but the treatment with the combination of ACEi and ARB proved successful and reliable, usually superior to application of a single drug in the slowing the progression of chronic kidney disease and development of end-organ damage (Azizi and Ménard 2004, Carlstrom et al. 2015, Cao et al. 2001, Cortinovis et al. 2016, Červenka and Heller 1996, Doleželová et al. 2016, Ke et al. 2000, Kobori et al. 2007, Kujal et al. 2014, Macconi 2010, Richer et al. 1998, Remuzzi et al. 2002, Remuzzi et al. 2016, Sen et al. 2008, Shen et al. 1998, Sedláková et al. 2017, Zoja et al. 2006, Zoja et al. 2002). Experimental work obviously aims to bring about some progress in future treatment of patients so the discrepancy between the effects in the experiment and the clinics appeared to preclude the translation of experimental results to human medicine. Can this situation be remedied in some way? And should the experimenters continue using combination of ACEi and ARB even though the dual therapy does not seem, at present, applicable to clinical medicine? Since common sense, as invoked above, has not a status of a scientific method any more, to resolve the dilemma it is necessary to look critically at the hard underlying evidence.

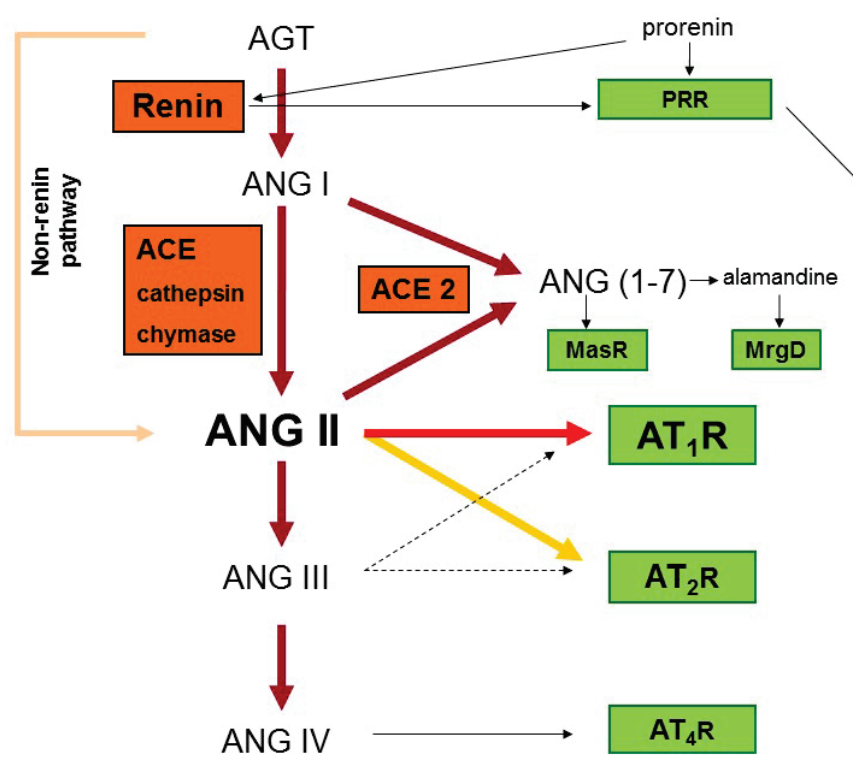

Fig. 1. Schematic illustration of the reninangiotensin system cascade without aldosterone pathway. ANG I, angiotensin I; ACE, angiotensin-converting enzyme; ANG II, angiotensin II; ANG III, angiotensin III; ANG IV, angiotensin IV; ACE2, angiotensinconverting enzyme type 2; ANG-(1-7), angiotensin 1-7; $A T_{1} R$, angiotensin type 1 receptor; $A T_{2} R$, angiotensin type 2 receptor; $\mathrm{AT}_{4} \mathrm{R}$, angiotensin type 4 receptor; MasR, Mas receptor (receptor for angiotensin 1-7); PRR, (pro)renin receptor; MAP kinases, mitogen-activated protein kinases; ERK, extracellular signal-related kinase; TGF $\beta$, transforming growth factor $\beta$; PAI-1, plasminogen activator inhibitor-1; MrgD, Mas-related G-protein coupled receptor.

\section{Basic information on the RAAS and its inhibitors}

The RAAS is a complex of enzymes, autacoids and hormones (Fig. 1) that plays important role in the regulation of blood pressure, sodium and potassium balance, organ remodeling and many other processes. The most important RAAS element is the hormonal peptide angiotensin II (ANG II), acting on different receptors, mainly angiotensin II receptor type $1\left(\mathrm{AT}_{1}\right)$. This increases blood pressure, mediates sodium retention by the kidney independently of aldosterone effect, and stimulates the release of aldosterone from the adrenal glands. Activation of $\mathrm{AT}_{1}$ receptors by $\mathrm{ANG}$ II has also important role in the pathogenesis of organ damage in hypertension, diabetes, myocardial ischemia and many other conditions (Braunwald 2015, Catalá-López et al. 2016, Hall et al. 2013, Hartupee and Mann 2017, Kobori et al. 2007, Macconi 2010, Ruster and Wolf 2006). Increasing knowledge of these effects has led to development of several groups of drugs interfering with this system: 
First, direct renin inhibitors; however, the only one that has reached clinical application was aliskiren, which has now been withdrawn from the European market.

Second, ACEi - the largest group of drugs interfering with RAAS, assumed to act mainly through the blockade of ANG II synthesis.

Third, ARB - the group which interferes with ANG II-mediated activation of $\mathrm{AT}_{1}$ receptors.

Fourth, aldosterone antagonists, the group in which prevents binding of aldosterone to mineralocorticoid receptor.

The fact that all the drugs in use are inhibitors or antagonists implies that RAAS activation is perceived (and in some conditions proven) as deleterious. On the other hand, intact RAAS is necessary during ontogenesis: knock-out animals lacking a part of this system usually have low blood pressure, but also display diminished growth and kidney damage (Niimura et al. 1995, Oliverio et al. 1998, Guron and Friberg 2000, Yosypiv 2014). Therefore all these drugs are contraindicated in pregnancy.

As mentioned above the RAS blockade is nowadays an integral part of treatment in hypertension, diabetes, heart failure, and kidney diseases. Since the system has a number of parallel pathways, combinations of drugs have been enthusiastically tested and used to improve the efficacy of treatment; one of the preferred was the ACEi and ARB combination, with effectiveness clearly supported by studies in animal models. There were even attempts to synthetize a combination molecule (Hashemzadeh et al. 2013). However, clinical trials and their meta-analyses have been disappointing.

\section{Results of animal studies}

In animals, ACEi and ARB have been used in conditions as remote as myocardial infarction and radiation nephropathy. To keep this review more concise, it will focus mainly on the treatment of elevated blood pressure, hypertensive organ damage and diabetic nephropathy and/or non-diabetic kidney disease, which are also the main areas where large human trials have been published.

Experiments and models where the combination of ACEi and $A R B$ was more effective than the use of a single drug interfering with the RAAS

There are numerous animal experiments where the combination of ACEi and ARB treatment was found superior to the use of one drug only. Better effects of the combined treatment were found in stroke prone spontaneously hypertensive rats (SHR-SP) (Dupuis et al. 2010). In Ren-2 transgenic rats, harboring additional mouse renin gene, the combination of ACEi and ARB was also more effective in blood pressure lowering and prevention of end-organ damage compared to single drug treatment (Kujal et al. 2014, Richer et al. 1998). A similar additive effect was described in rats harboring human renin and angiotensin gene (Mervaala et al. 1999). Spontaneously hypertensive rats (SHR) also benefited from the combination of ACEi and ARB versus single drug treatment with regard to antihypertensive and cardio- and renoprotective actions ( $\mathrm{Ke}$ et al. 2000). However, in Lyon hypertensive rat there was an additive blood pressure lowering effect but no positive effects on the course of end-organ damage (Naelten et al. 2005). In models of diabetic nephropathy the combination of ACEi and ARB also produced better organoprotective effects as compared with a single drug treatment; this was reported from studies of streptozotocin induced diabetes in rat (Sen et al. 2008) as well as diabetic SHR animals (Cao et al. 2001). Also other animals and conditions were treated successfully with the combination of ACEi and ARB, e.g. the pigs with congestive heart failure (Shen et al. 1998).

Experiments and models where the combination of ACEi and $A R B$ had no additive effect compared to the use of a single drug interfering with the RAAS

However, in other models and sometimes the same models in different experimental setting negative or inconsistent effects of dual therapy were observed. No additive effect of the treatment with the combination of ACEi and ARB as compared with single drug treatment on the incidence and severity of stroke in SHR-SP was found in a study by Thoene-Reineke et al. (2011). In addition, it was reported that the treatments with ACEi or ARB applied had different positive effects on myocardial cell proliferation but there were no additive positive effects of their combination (Taylor et al. 1998). Finally, inconsistent benefits of the treatment with the combination of ACEi and ARB as compared with single drug treatment were reported in animals with hypertension dependent on the pharmacologically induced deficiency of nitric oxide (Jover et al. 2001).

\section{Results of human trials}

In humans, the treatment with the combination of ACEi and ARB appeared effective with regard to some 
specific markers only, e.g. a reduction of proteinuria was seen (Bakris 2010, Pena-Planco and Fried 2016, Remmuzii et al. 2002, Taal and Brenner 2002, Ziff et al. 2016). To a considerable surprise, hard outcomes in large randomized trials did not indicate improvement and harmful side effects occurred more often. These included, but not were limited to, hyperkalemia, hypotension and increased incidence of renal function deterioration or renal failure (Fried et al. 2008, Mia et al. 2011, Onuigbo 2009, Parving et al. 2012, Yusuf and ONTARGET Investigators 2008b, Rutkowski and Tylicky 2015). At present, the treatment with the combination of ACEi and ARB is not recommended, but is not contraindicated, either, in case the patients is in need of effective blood pressure control; when applied, careful monitoring of adverse effects is obligatory (Rutkowski and Tylicky 2015, Ziff et al. 2016). It is known that ARB treatment, compared to ACEi, is less likely to induce cough. However, it is important to consider that one relevant metaanalysis demonstrated that treatment with ACEi reduced the mortality while the treatment with ARB did not (Van Vark et al. 2012). Thus, despite the potential risk of inducing cough the treatment with ACEi should be preferred as monotherapy in patients who can reasonably tolerate it and it also should be considered as the optimal standard treatment regime for comparison with new treatments that should eventually demonstrate additional beneficial effects in comparison with the treatment with ACEi.

Clinical studies where the combination of ACEi and ARB had no additive effect compared to a single drug interfering with the RAAS

In the ONTARGET study, single blockade of the RAS achieved either by the treatment with the ACEi (ramipril) or by the ARB (telmisartan) was equally effective when assessed using a combined end point of mortality and morbidity, in patients with high risk for cardiovascular diseases (Yusuf and ONTARGET Investigators 2008b). The treatment with the combination of ACEi and ARB (ramipril and telmisartan) did not improve the clinical outcome as compared with single drug RAAS blockade, however, adverse effects, e.g. hyperkalemia, hypotension and acute renal failure were reported more often (Fried et al. 2013, Yusuf and ONTARGET Investigators 2008b, Rutkowski and Tylicki 2015). Patients who did not tolerate ACEi and could not be enrolled into the ONTARGET and were therefore randomized to the TRANSCEND study for single ARB treatment (telmisartan), did not show any deterioration, nor improvement of the primary outcome (Yusuf and TRANSCEND Investigators 2008a). However, post-hoc analysis of these two large trials (ONTARGET and TRANSCEND) did not reveal any additional cardio- and renoprotective effects of the treatment with the combination of ACEi and ARB compared to monotherapy (Yusuf and ONTARGET Investigators 2008b, Yusuf and TRANSCEND Investigators 2008a). Conversely, in the subpopulation of patients with lower glomerular filtration rate and macroalbuminuria the dual RAS blockade resulted in a higher rate of hyperkalemia and acute renal failure. The conclusion of this post-hoc analysis was that there is currently no evidence of cardiovascular or renal benefit of the combined RAAS blockade over the single drug variant (Tobe et al. 2011). Moreover, the SUPPORT study demonstrated that adding olmesartan (ARB) to the standard treatment with ACEi resulted in a higher incidence of acute renal failure events (Sakata et al. 2015). Furthermore, it has been reported that among elderly patients the treatment with combination of ACEi and ARB was associated with increased risk of adverse renal outcomes and hyperkalemia as compared with treatment based on single RAS blockade (McAlister et al. 2011). Another study, performed in patients with autosomal dominant polycystic kidney disease manifesting itself as chronic kidney disease (CKD) at stage 3 , showed that the treatment with the combination of ACEi and ARB did not bring any additional benefits as compared with patients treated with ACEi only (Torres et al. 2014). Recent meta-analyses of adult patients with diabetes which include 71 clinical trials with 103120 participants showed similar effects of treatment with either ACEi or ARB on major cardiovascular and renal outcomes. Most important, they failed to prove any significant benefit regarding those major outcomes of the combined therapy with ACEi and ARB (Catalá-López et al. 2016). Similar results have been obtained in another metaanalysis study (Palmer et al. 2015). It has also been found that dietary sodium restriction (target: $50 \mathrm{mmol} \mathrm{Na}{ }^{+} /$day) in patients with non-diabetic CKD treated with ACEi is more effective in reducing proteinuria and decreasing blood pressure compared to dual RAS blockade combining ACEi and ARB in patients on regular sodium diet (target: $200 \mathrm{mmol} \mathrm{Na}^{+} /$day) (Slagman et al. 2001). Nevertheless, it should be admitted that in real life it is difficult to achieve patients' adherence to low sodium diet: most probably, adherence to taking one additional drug a day 
would be much easier to accomplish.

Even more confusing is the assessment of the effects of aldosterone antagonists. Since numerous studies have demonstrated a critical role of aldosterone in the pathophysiology of progression of CKD and development of end-stage renal disease (Bolignano et al. 2014, Dhaybi and Bakris 2017), and because it has been shown that even the combined treatment with ACEi and ARB resulted in incomplete suppression of increased serum aldosterone levels ("aldosterone escape phenomenon"), addition of aldosterone blockers to the treatment either with ACEi or ARB has been suggested (Bolignano et al. 2014, Dhaybi and Bakris 2017). This proposal has been further supported by findings that such treatment with aldosterone blockers in patients with CKD reduced proteinuria and improved renal outcomes (Dhaybi and Bakris 2017). Therefore, it has been proposed that addition of an aldosterone antagonist to either ACEi or ARB treatment could be a new approach to the treatment of patients with CKD, despite the risk of hyperkalemia and further impairment of renal function. However, the comprehensive meta-analysis performed by Bolignano and co-workers showed that such addition did not disclose any beneficial effects, such as reducing major cardiovascular events or inhibiting the development of end-stage renal disease in patients with $\mathrm{CKD}$, even when aldosterone antagonist was added to the combined treatment with ACEi and ARB (Bolignano et al. 2014).

Clinical studies where the combination of ACEi and ARB revealed additional beneficial effects compared to the use of a single drug interfering with the RAAS

Some of studies revealed superior effects of the treatment with the combination of ACEi and ARB compared to the use of one drug only, however, these studies were focused on cardiovascular and not renal pathology. In Val-HeFT study, the positive effect of the ACEi plus ARB treatment on the combined end point (mortality and morbidity) was shown in patients with heart failure (Cohn et al. 2001), and these findings were later confirmed for a different ARB drug (Gremmler et al. 2007). In addition, it was reported that the treatment with the combination of ACEi and ARB significantly reduced all-cause mortality, cardiovascular death, and heart failure-related hospitalizations in hemodialysis patients, as compared to the treatment with ACEi only (Cice et al. 2010). Furthermore, these findings were confirmed by studies performed within CHARM program, showing again that the treatment with the combination of ACEi and ARB was more effective than the use of ACEi alone in reducing the cardiovascular mortality and frequency of hospitalization required for patients with worsening of heart failure (McMurray et al. 2003, McMurray et al. 2006).

\section{Why the difference between the results of experimental and clinical studies? Analysis of possible reasons}

It is critically important to recognize that the comparison of results of experiments and clinical studies is difficult in many respects; therefore, direct translation of the results of experimental studies to the clinical practice is not possible. This is so for at least four major reasons.

\section{Species differences regarding $R A A S$ characteristics}

Even though the structure and function(s) of the RAAS as a whole and its components are highly conserved among mammals, some important differences are evident, e.g. different activity of renin. For instance, $\mathrm{pH}$ optimum of rat versus mouse renin differs and both are also different from the optimum for human renin. There are also differences in other enzymes, in the synthesis of substrates, or the density and other properties of receptors; e.g. there are three subtypes of $\mathrm{AT}_{1}$ receptors in rodents but only one in humans (Balakumar and Jagadeesh 2014, Hall et al. 2013). It is important to remember that the variability in the RAAS is relatively well-known in animals while the knowledge about the RAAS in humans is understandably limited: many in vivo animal studies cannot be repeated in humans (except for cell culture studies).

\section{Well-defined condition or disease in animal experiments versus diversity in humans}

The cause of the disease or condition in an animal is well known (genetic manipulation, surgery or other treatment, diet, drugs, etc.). The age and time of onset is either known or chosen by the researcher and does not differ significantly between experimental groups. On the other hand, the trials in humans include individuals of different age, not precisely known duration of chronic conditions, and, not infrequently, entirely different underlying primary disease. The best example is the progression CKD in nondiabetic diseases: extreme diversity of initial pathological insult can substantially 
and unpredictably affect the clinical outcomes of any treatment regime. In contrast, an animal model that in experimental studies is commonly used to mimic the progression of CKD in nondiabetic diseases is strictly defined: 5/6 renal mass reduction (unilateral nephrectomy plus removal of two-thirds of the contralateral kidney, $5 / 6 \mathrm{NX}$ ), which leads to highly reproducible course of progression of CKD to end-stage renal disease, characterized by typical systemic and intrarenal activation of the RAAS, and predictable pathomorphological alterations in the remnant kidney (Carlstrom et al. 2015, Červenka and Heller 1996, Kobori et al. 2007, Kujal et al. 2014, Neuringer and Brenner 1993, Remmuzi et al. 2002, Sedláková et al. 2017, Shimamura and Morrison 1975, Zoja et al. 2006).

\section{Differences in the genetic background and other confounding factors}

It is important to recognize that animal experiments are usually performed in inbred strains, i.e. in genetically almost identical animals, very often only of gender. In addition, animals enter studies at approximately the same age. Animals are maintained under standard living conditions, they are exposed to the same diet of controlled properties (including precisely controlled protein and salt intake etc.). If not otherwise planned for the actual experimental design, they have no co-morbidities and no drug treatment other than the medication studied. Moreover, in long term experiments their sleeping habits and physical activity do not change from day to day and the animals fully adhere to the protocol. Last but not least, individual component procedures of the experiment are performed by one or only a small group of investigators, which ensures standard treatment throughout the study.

There is no doubt that none of the above circumstances and characteristics can be achieved in human clinical trials. Therefore, to obtain strong evidence for a positive outcome of a treatment of the disease such as CKD, large multicenter trials are needed and they usually include individuals of African, Asian and Caucasian origin. Evidently, the variability of genetic background, lifestyle, diet, co-morbidities and concomitant medication is enormous, and in addition, at least some of the circumstances might change substantially in the course of the clinical study. It will also be noted that the staff performing the clinical trial is recruited in hundreds of diverse centers in different parts of the world. Even if the staff is usually well trained, they might have different ways of approach to patients. The compliance of these is never guaranteed and it usually progressively declines over time.

\section{Methodological differences between animal experiments and clinical studies}

Termination due to adverse events

It is important to recognize that in animal experiments no study is terminated because of adverse effects of the treatment regime. Since the deleterious effects of medication do not usually increase the mortality, they will probably go unnoticed until the end of experiment. For example, in experimental kidney disease plasma potassium concentrations are rarely, if ever, measured in the course of experiment, and therefore hyperkalemia would not be diagnosed at all. On the contrary, it is much feared in humans, so plasma potassium is frequently checked and strictly controlled, even in asymptomatic individuals, and many patients tending to develop hyperkalemia would be excluded from the study. Hypotension is another good example: if it does not interfere with the design of the experiment, it will not change the protocol or lead to withdrawal of the drug in animals. The same is true for acute renal failure: the higher incidence of acute renal failure in the control (untreated) group of animals is not a hint for any treatment intervention, which is a situation that is unacceptable in clinical trials. For all these and many other reasons some patients are excluded from studies, protocols are changed while the study is under way, or the trial might be prematurely terminated.

\section{Differences in statistical analysis}

Statistical analysis in clinical trials uses two main approaches: "intention-to-treat" includes all patients as originally randomized, while "per protocol" includes only those patients who completed the whole treatment protocol to which they were originally allocated (Lachin 2000, Montorni and Guyatt 2001). As animals are not withdrawn from the assigned treatment regimens even though their condition during the study has obviously deteriorated, the intention-to-treat and per protocol analysis include the same individuals. In human medicine most studies implement "intention-to-treat" approach to reflect real impact of the treatment on the whole population treated, not only on the patients who were able to adhere to the protocol from the beginning to the end of the study. Thus, the "treated group" might then include substantial proportion of individuals who received the 
drug for only negligible period of time. On the other hand, if the studied procedure or drug allows, the patients assigned to placebo group are often given active treatment when necessary. This is also an important factor determining why at the end of a clinical trial the "treated group" and "control group" differ much less than expected.

Publication bias: negative results of animal experiments not publishable

Even if we do not have robust data (it is not officially available and therefore cannot be "scientifically evaluated"), there is no doubt that the proportion of unpublished "negative studies" would be significantly higher in animal experiments than in clinical trials. It can be assumed that a properly conducted large multicenter clinical study will always be published, even if the results proved negative or the study was prematurely terminated because of unforeseen reasons. In contrast, animal experiments that have not yielded expected results (e.g. did not show further renoprotective effect of additional new treatment on the progression of CKD after 5/6 NX) will not probably even be considered for publication and, even if so, they will probably be rejected because "they do not provide any new information that would have potential clinical implication for the treatment of patients".

\section{Conclusions}

In contrast to common opinion, it is not true that all animal experiments evaluating the effects of the combined treatment with ACEi and ARB on the development of end-organ damage yielded positive results, or that all clinical studies were negative or even showed detrimental effects. Our analysis shows that the combination of ACEi and ARB was the most effective treatment regime in animal models with RAAS-dependent hypertension and some degree of organ damage; the results were less convincing in other animal models. Therefore we postulate that ACEi plus ARB combination should remain the standard control treatment regime in the models in which beneficial effects have been convincingly proven. In the models where such combined treatment was not conclusively better, a single drug RAAS blockade (either ACEi or ARB) should be used.
With regard to clinical studies, we conclude that in human diseases there are currently no proven benefits of the combined ACEi and ARB over single drug RAAS blockade. Given the high risk of serious complications, dual RAAS blockade cannot be currently recommended as the therapy of choice, even in patients with heavy proteinuria. This has been confirmed in large medical trials and meta-analyses and thus it is considered to be evidence based. However, even if human are born free and equal, they are not uniform. Thus the new emerging trend is to change both the design of the trials and interpretation of the results (Bhatt and Mehta 2016, Yusuf and Wittes 2016). Instead of implementing new methods non-selectively, the effort should be directed on finding specific populations (defined by genetic markers or features of the disease or other parameters) that will have most profit and/or least risk from any particular treatment regime. More distant future will probably bring "tailoring" of the treatment to each individual, not simply to a group or a disease. Therefore it is now considered that dual RAAS blockade may be an interesting alternative in selected patients, for instance young patients with nondiabetic CKD running with hypertension and high proteinuria, provided that they are likely to adhere to dietary potassium restriction (Rutkowski and Tylicki 2015). However, such patient groups are still in the process of being tested and the results are not yet available (SONAR trial).

On the whole, despite obvious reservations and limitations, continuation of experimental studies of the effects of dual RAAS blockade should be regarded clinically relevant because they expand our understanding of the background of long-term renoprotective effects of such blockade in the prevention of CKD progression. The studies remain an important prerequisite for the development of novel therapeutic strategies aimed at slowing the progression of CKD in human beings.

\section{Conflict of Interest}

There is no conflict of interest.

\section{Acknowledgements}

This study was primarily supported by the Ministry of Health of the Czech Republic grant no. 15-28671A to V.Č.Ch. All rights reserved. 


\section{References}

AZIZI M, MÉNARD J: Combined blockade of the renin-angiotensin system with angiotensin-converting enzyme inhibitors and angiotensin II type 1 receptor antagonists. Circulation 109: 2492-2499, 2004.

BAKRIS GL: Dual RAAS blockade is desirable in kidney disease: Con. Kidney Int 78: 546-549, 2010.

BALAKUMAR P, JAGADEESH G: Structural determinants for binding, activation, and functional selectivity of the angiotensin AT1 receptor. J Mol Endocrinol 53: 71-92, 2014.

BAVISHI C, BANGALORE S, MESSERLI FH: Renin-angiotensin-aldosterone system inhibitors in hypertension: is there evidence for benefit independent of blood pressure reduction? Prog Cardiovas Dis 59: 253-261, 2016.

BHATT DL, MEHTA C: Adaptive designs for clinical trials. $N$ Engl J Med 375: 65-74, 2016.

BOLIGNANO D, PALMER SC, NAVANEETHAN SD, STRIPPOLI, GF: Aldosterone antagonists for preventing the progression of chronic kidney disease. Cochrane Database Syst Rev: CD007004, 2014.

BRAUNWALD E: The war against heart failure: the Lancet lecture. Lancet 385: 812-824, 2015.

CARLSTROM M, WILCOX CS, ARENDSHORST WJ: Renal autoregulation in health and disease. Physiol Rev 95: 405-511, 2015.

CAO Z, BONNET F, DAVIS B, ALLEN TJ, COOPER ME: Additive hypotensive and anti-albuminuric effects of angiotensin-converting enzyme inhibition and angiotensin receptor antagonism in diabetic spontaneously hypertensive rats. Clin Sci (Lond) 100: 591-599, 2001.

CATALÁ-LÓPEZ F, MACÍAS SAINT-GERONS D, GONZÁLEZ-BERMEJO D, ROSANO GM, DAVIS BR, RIDAO M, ZARAGOZA A, MONTERO-COROMINAS D, TOBÍAS A, DE LA FUENTE-HONRUBIA C, TABARÉS-SEISDEDOS R, HUTTON B: Cardiovascular and renal outcomes of renin-angiotensin system blockade in adult patients with diabetes mellitus: a systematic review with network meta-analyses. PLoS Med 13: e1001971, 2016.

CICE G, Di BENEDETTO A, D'ISA S, D'ANDREA A, MARCELli D, GATTI E, CALABRÒ R: Effects of telmisartan added to angiotensin-converting enzyme inhibitors on mortality and morbidity in hemodialysis patients with chronic heart failure a double-blind, placebo-controlled trial. J Am Coll Cardiol 56: 1701-1708, 2010.

CHAUGAI S, SHERPA LY, SEPEHRY AA, ARIMA H, WANG DW: Effect of RAAS blockers on adverse clinical outcomes in high CVD risk subjects with atrial fibrilation: a meta-analysis and systemic review of randomized controlled trials. Medicne (Baltimore) 96: e4059, 2016.

COHN JN, TOGNONI G; VALSARTAN HEART FAILURE TRIAL INVESTIGATORS: A randomized trial of the angiotensin-receptor blocker valsartan in chronic heart failure. N Engl J Med 345: 1667-1675, 2001.

CORTINOVIS M, RUGGENENTI P, REMUZZI G: Progression, remission and regression of chronic renal diseases. Nephron 134: 20-24, 2016.

ČERVENKA L, HELLER J: Comparison of the effects of a low-protein diet with the effects of a converting enzyme inhibitor on the progression of renal insufficiency in hypertensive rats. Ren Fail 18: 173-180, 1996.

DHAYBI OA, BAKRIS G: Mineralocorticoid antagonists in chronic kidney disease. Curr Opin Nephrol Hypertens 26: 50-55, 2017.

DOLEŽELOVÁ Š, JÍCHOVÁ Š, HUSKOVÁ Z, VOJTÍŠKOVÁ A, KUJAL P, HOŠKOVÁ L, KAUTZNER J, SADOWSKI J, ČERVENKA L, KOPKAN L: Progression of hypertension and kidney diseas in aging fawnhooded rats is mediated by enhanced influence of renin-angiotensin system and suppression of nitric oxide system and epoxyeicosanoids. Clin Exp Hypertens 38: 644-651, 2016.

DUPUIS F, VINCENT JM, LIMIÑANA P, CHILLON JM, CAPDEVILLE-ATKINSON C, ATKINSON J: Effects of suboptimal doses of the AT1 receptor blocker, telmisartan, with the angiotensin-converting enzyme inhibitor, ramipril, on cerebral arterioles in spontaneously hypertensive rat. J Hypertens 28: 1566-1573, 2010.

FRIED LF, EMANUELE N, ZHANG JH, BROPHY M, CONNER TA, DUCKWORTH W, LEEHEY DJ, MCCULlOUGH PA, O'CONNOR T, PALEVSKY PM, REILlY RF, SELIGER SL, WARREN SR, WATNICK S, PEDUZZI P, GUARINO P; VA NEPHRON-D INVESTIGATORS: Combined angiotensin inhibition for the treatment of diabetic nephropathy. N Eng J Med 369: 1892-1903, 2013. 
GRANDI AM, SOLBIATI F, LAURITA E, MARESCA AM, NICOLINI E, MARCHESI C, GIANNI M, GUASTI L, VENCO A: Effects of dual blockade of renin-angiotensin system on concentric left ventricular hypertrophy in essential hypertension: a randomized, controlled pilot study. Am J Hypertens 21: 231-237, 2008.

GREMMLER B, KISTERS K, KUNERT M, SCHLEITING H, ULBRICHT LJ: Effects of different AT1-receptor antagonists in the therapy of severe heart failure pretreated with ACE inhibitors. Acta Cardiol 62: 321-328, 2007.

GURON G, FRIBERG P: An intact renin-angiotensin system is a prerequisite for normal renal development. J Hypertens 18: 123-137, 2000.

HALL JE, GRANGER JP, HALL ME: Physiology and pathophysiology of hypertension. In: Seldin and Giebisch's the Kidney: Physiology and Pathophysiology. Fifth edition. ALPERN RJ, MOE OW, CAPLAN M (eds), Elsevier Inc., 2013, pp 1319-1354.

HARTUPPE J, MANN DL: Neurohormonal activation in heart failure with reduced ejection fraction. Nat Rev Cardiol 14: 30-38, 2017.

HASHEMZADEH M, PARK S, JU H, MOVAHED MR: A novel design of combining the angiotensin converting enzyme (ACE) inhibitor captopril with the angiotensin receptor blocker (ARB) losartan using homo coupling via PEG diacid linker. Recent Pat Cardiovasc Drug Discov 8: 221-225, 2013.

JOVER B, HERIZI A, CASELLAS D, MIMRAN A: Influence of irbesartan and enalapril on changes of renal function associated with the established phase of L-NAME hypertension. J Hypertens 19: 2039-2046, 2001.

KE YS, CAO H, YANG, T: Effect of combination of valsartan with benazepril on blood pressure and left ventricular hypertrophy in SHR. Acta Pharmacol Sin 21: 1043-1047, 2000.

KOBORI H, NAGAKU M, NAVAR LG, NISHIYAMA A: The intrarenal renin-angiotensin system: from physiology to the pathobiology of hypertension and kidney disease. Pharmacol Rev 59: 251-287, 2007.

KUJAL P, ČERTÍKOVÁ CHÁBOVÁ V, ŠKAROUPKOVÁ P, HUSKOVÁ Z, VERNEROVÁ Z, KRAMER HJ, WALKOWSKA A, KOMPANOWSKA-JEZIERSKA E, SADOWSKI J, KITADA K, NISHIYAMA A, HWANG SH, HAMMOCK BD, IMIG JD, ČERVENKA L: Inhibition of soluble epoxide hydrolase is renoprotective in 5/6 nephrectomized Ren-2 transgenic hypertensive rats. Clin Exp Pharmacol Physiol 41: 227-237, 2014.

LACHIN JM: Statistical considerations in the intent-to-treat principle. Control Clin Trials 21: 167-189, 2000.

MCALISTER FA, ZHANG J, TONELLI M, KLARENBACH S, MANNS B J, HEMMELGARN BR; ALBERTA KIDNEY DISEASE NETWORK: The safety of combining angiotensin-converting-enzyme inhibitors with angiotensin-receptor blockers in elderly patients: a population-based longitudinal analysis. CMAJ 183: 655-662, 2011.

MCMURRAY JJ, OSTERGREN J, SWEDBERG K, GRANGER CB, HELD P, MICHELSON EL, OLOFSSON B, YUSUF S, PFEFFER MA; CHARM INVESTIGATORS AND COMMITTEES: Effects of candesartan in patients with chronic heart failure and reduced left-ventricular systolic function taking angiotensin-convertingenzyme inhibitors: the CHARM-Added trial. Lancet 362: 767-771, 2003.

MCMURRAY JJ, YOUNG JB, DUNLAP ME, GRANGER CB, HAINER J, MICHELSON EL, EARLE S, OLOFSSON B, OSTERGREN J, YUSUF S, SWEDBERG K, PFEFFER MA; CHARM INVESTIGATORS: Relationship of dose of background angiotensin-converting enzyme inhibitor to the benefits of candesartan in the Candesartan in Heart failure: Assessment of Reduction in Mortality and morbidity (CHARM)-Added trial. Am Heart J 151: 985-991, 2006.

MACCONI D: Targeting the renin-angiotensin system for remission/regression of chronic kidney disease. Histol Histopathol 25: 655-668, 2010.

MERVAALA E, DEHMEL B, GROSS V, LIPPOLDT A, BOHLENDER J, MILIA AF, GANTEN D, LUFT FC: Angiotensin-converting enzyme inhibition and AT1 receptor blockade modify the pressure-natriuresis relationship by additive mechanisms in rats with human renin and angiotensinogen genes. J Am Soc Nephrol 10: 1669-1680, 1999. 
MIAO Y, DOBRE D, LAMBERS HEERSPINK HJ, BRENNER BM, COOPER ME, PARVING HH, SHAHINFAR S, GROBBEE D, DE ZEEUW D: Increased serum potassium afftects renal outcomes: a post hoc analysis of the reduction of endpoints in NIDDM with the angiotensin II antagonist losartan (RENAAL) trial. Diabetologia 54: 44-50, 2011.

MONTORI VM, GUYATT GH: Intention-to-treat principle. CMAJ 165: 1339-1341, 2001.

NAELTEN G, TRIGO LF, LO M: Blood pressure and proteinuria after cessation of a brief renin-angiotensin system blockade in young and adult Lyon hypertensive rats. J Cardiovasc Pharmacol 46: 740-745, 2005.

NEURINGER JR, BRENNER BM: Hemodynamic theory of progressive renal disease: a 10-year update in brief review. Am J Kidney Dis 22: 98-104, 1993.

NIIMURA F, LABOSKY PA, KAKUCHI J, OKUBO S, YOSHIDA H, OIKAWA T, ICHIKI T, NAFTILAN AJ, FOGO A, INAGAMI T, HOGAN BLM, ICHIKAWA I: Gene targeting in mice reveals a requirment for angiotensin in the development and maintenance of kidney morphology and growth factor regulation. $J$ Clin Invest 96: 2947-2954, 1995.

OLIVERIO MI, KIM HS, ITO M, LE T, AUDOLY L, BEST CF, HILLER S, KLUCKMAN K, MAEDA N, SMITHIES O, COFFMAN TM: Reduced growth, abnormal kidney structure, and type 2 (AT2) angiotensin receptor-mediated blood pressure regulation in mice lacking both AT1A and AT1B receptors for angiotensin II. Proc Natl Acad Sci U S A 95: 15496-15501, 1998.

ONUIGBO MA: Analytic review of the evidence for renoprotection by renin-angiotensin-aldosterone system blockade in chronic kidney disease - a call for caution. Nephron Clin Pract 113: c63-c70, 2009.

ORSBORNE C, CHAGGAR PS, SHAW SM, WILLIAMS SG: The renin-angiotensin-aldosterone system in heart failure for the non-specialist: the past, the present and the future. Postgrad Med J 93: 29-37, 2017.

PALMER SC, MAVRIDIS D, NAVARESE E, CRAIG JC, TONELLI M, SALANTI G, WIEBE N, RUOSPO M, WHEELER DC, STRIPPOLI GF: Comparative efficacy and safety of blood pressure-lowering agents in adults with diabetes and kidney disease: a network meta-analysis. Lancet 385: 2047-2056, 2015.

PARVING HH, BRENNER BM, MCMURRAY JJ, DE ZEEUW D, HAFFNER SM, SOLOMON SD, CHATURVEDI N, PERSSON F, DESAI AS, NICOLAIDES M, RICHARD A, XIANG Z, BRUNEL P, PFEFFER MA; ALTITUDE INVESTIGATORS: Cardiorenal end points in a trial of aliskiren for type 2 diabetes. $N$ Engl J Med 367: 2204-2213, 2012.

PENA-PLANCO JE, FRIED LF: Established and emerging strategies in the treatment of chronic kidney disease. Semin Nephrol 36: 331-342, 2016.

PTINOPOLOU AG, PIKILIDOU MI, LASARIDIS N: The effect of antihypertensive drugs on chronic kidney disease: a comprihensive review. Hypertens Res 36: 91-101, 2013.

REMMUZI A, GAGLIARDINN E, DONADONI C, FASSI A, SANGALLI F, LEPRE MS, REMUZZI G, BENIGNI A: Effect of angiotensin II antagonism on the regression of kidney disease in the rat. Kidney Int 62: 885-894, 2002.

REMMUZZI A, SANGALLI F, MACCONI D, TOMASONI S, CATTANEO I, RIZZO P, BONANDRINI B, BRESCIANI E, LONGARETTI L, GAGLIARDINI E, CONTI S, BENIGNI A, REMUZZI G: Regression of renal disease by angiotensin II antagonism is caused by regeneration of kidney vasculature. J Am Soc Nephrol 27: 699-705, 2016.

REMUZZI G, RUGGENENTNI P, PERICO N: Chronic renal disease: renoprotective benefits of renin-angiotensin system inhibition. Ann Intern Med 136: 604-615, 2002.

RICHER C, BRUNEVAL P, MÉNARD J, GIUDICELLI JF: Additive effects of enalapril and losartan in (mREN-2)27 transgenic rats. Hypertension 31: 692-698, 1998.

RUSTER C, WOLF G: Renin-angiotensin-aldosterone system and progression of renal disease. J Am Soc Nephrol 17: 2985-2991, 2006.

RUTKOWSKI B, TYLICKI L: Nephroprotective action of renin-angiotensin-aldosterone system blockade in chronic kidney disease patients: the landscape after ALTITUDE and VA Nephron-D Trails. J Ren Nutr 25: 194-200, 2015. 
SAKATA Y, SHIBA N, TAKAHASHI J, MIYATA S, NOCHIOKA K, MIURA M, TAKADA T, SAGA C, SHINOZAKI T, SUGI M, NAKAGAWA M, SEKIGUCHI N, KOMARU T, KATO A, FUKUCHI M, NOZAKI E, HIRAMOTO T, INOUE K, GOTO T, OHE M, TAMAKI K, IBAYASHI S, ISHIDE N, MARUYAMA Y, TSUJI I, SHIMOKAWA H; SUPPORT TRIAL INVESTIGATORS: Clinical impacts of additive use of olmesartan in hypertensive patients with chronic heart failure: the supplemental benefit of an angiotensin receptor blocker in hypertensive patients with stable heart failure using olmesartan (SUPPORT) trial. Eur Heart J 36: 915-923, 2015.

SEN S, SANIYE S, KANTER M, MEHMET K, USTUNDAG S, SEDAT U, AKTAS C, CEVAT A, DOGUTAN H, YALCIN O, OMER Y: Effect of angiotensin-converting enzyme inhibition and angiotensin II type 1 receptor blockade on streptozotocin-induced diabetic nephropathy. Ren Fail 30: 1023-1033, 2008.

SHEN YT, WIEDMANN RT, GREENLAND BD, LYNCH JJ, GROSSMAN W: Combined effects of angiotensin converting enzyme inhibition and angiotensin II receptor antagonism in conscious pigs with congestive heart failure. Cardiovasc Res 39: 413-422, 1998.

SEDLÁKOVÁ L, ČERTÍKOVÁ CHÁBOVÁ V, DOLEŽELOVÁ Š, ŠKAROUPKOVÁ P, KOPKAN L, HUSKOVÁ Z, ČERVENKOVÁ L, KIKERLOVÁ S, VANĚČKOVÁ I, SADOWSKI J, KOMPANOWSKA-JEZIERSKA E, KUJAL P, KRAMER HJ, ČERVENKA L: Renin-angiotensin system blockade alone or combined with $\mathrm{ET}_{\mathrm{A}}$ receptor blockade: effects on the course of chronic kidney disease in 5/6 nephrectomized Ren-2 transgenic hypertensive rats. Clin Exp Hypertens 39: 183-195, 2017.

SHIMAMURA T, MORRISON AB: A progressive glomerulosclerosis occurring in partial five-sixth nephrectomized rats. Am J Physiol 79: 95-106, 1975.

SLAGMAN MC, WAANDERS F, HEMMELDER MH, WOITTIEZ AJ, JANSSEN WM, LAMBERS HEERSPINK HJ, NAVIS G, LAVERMAN GD; HOLLAND NEPHROLOGY STUDY GROUP: Moderate dietary sodium restriction added to angiotensin converting enzyme inhibition compared with dual blockade in lowering proteinuria and blood pressure: randomised controlled trial. BMJ 343: $\mathrm{d} 4366,2001$.

SONAR trial: Study of diabetic nephropathy with Atresantan. ClinicalTrials.gov no. NCT01858532 (http://clinicaltrilas.gov/ct2/show/ NCT01858532).

TAAL M, BRENNER B: Combination ACEi and ARB therapy: additional benefit in renoprotection. Curr Opin Nephrol Hypertens 11: 377-381, 2002.

TAYLOR K, PATTEN RD, SMITH JJ, ARONOVITZ MJ, WIGHT J, SALOMON RN, KONSTAM MA: Divergent effects of angiotensin-converting enzyme inhibition and angiotensin II-receptor antagonism on myocardial cellular proliferation and collagen deposition after myocardial infarction in rats. $J$ Cardiovasc Pharmacol 31: 654-660, 1998.

THOENE-REINEKE C, RUMSCHÜSSEL K, SCHMERBACH K, KRIKOV M, WENGENMAYER C, GODES M, MUELLER S, VILLRINGER A, STECKELINGS U, NAMSOLLECK P, UNGER T: Prevention and intervention studies with telmisartan, ramipriland their combination in different rat stroke models. PLoS One 6 : e23646, 2011.

TOBE SW, CLASE CM, GAO P, MCQUEEN M, GROSSHENNIG A, WANG X, TEO KK, YUSUF S, MANN JF; ONTARGET AND TRANSCEND INVESTIGATORS: Cardiovascular and renal outcomes with telmisartan, ramipril, or both in people at high renal risk: results from the ONTARGET and TRANSCEND studies. Circulation 123: 1098-1107, 2011.

TORRES VE, ABEBE KZ, CHAPMAN AB, SCHRIER RW, BRAUN WE, STEINMAN TI, WINKLHOFER FT, BROSNAHAN G, CZARNECKI PG, HOGAN MC, MISKULIN DC, RAHBARI-OSKOUI FF, GRANTHAM JJ, HARRIS PC, FLESSNER MF, MOORE CG, PERRONE RD; HALT-PKD TRIAL INVESTIGATORS: Angiotensin blockade in late autosomal dominant polycystic kidney disease. $N$ Engl J Med 371: 2267-2276, 2014.

TURNER JM, BAUER C, ABRAMOWITZ MK, MELAMED ML, HOSTETTER TH: Treatment of chronic kidney disease. Kidney Int 81: 351-362, 2012. 
VAN VARK LC, BERTRAND M, AKKERHUIS KM, BRUGTS JJ, FOX K, MOURAD JJ, BOERSMA E: Angiotensin-converting enzyme inhibitors reduce mortality in hypertension: a meta-analysis of randomized clinical trials of renin-angiotensin-aldosterone system inhibitors involving 158,998 patients. Eur Heart $J$ 33: 2088-2097, 2012.

VEJAKAMA P, THAKKINSTIAN A, LERTRATTANANON D, INGSATHIT A, NGARMUKOS C, ATTIA J: Reno-protective effects of renin-angiotensin system blockade in type 2 diabetic patients: a systematic review and network meta-analysis. Diabetologia 55: 566-578, 2012.

YOSYPIV IV: Renin-angiotensin system in ureteric bud branching morphogenesis: implications for kidney disease. Pediatr Nephrol 29: 609-620, 2014.

YUSUF S, TEO K, ANDERSON C, POGUE J, DYAL L, COPLAND I, SCHUMACHER H, DAGENAIS G, SLEIGHT P ON BEHALF OF TRANSCEND INVESTIGATORS: Effects of the angiotensin-receptor blocker telmisartan on cardiovascular events in high-risk patients intolerant to angiotensin-converting enzyme inhibitors: a randomised controlled trial. Lancet 372: 1174-1183, 2008a.

YUSUF S, TEO KK, POGUE J, DYAL L, COPLAND I, SCHUMACHER H, DAGENAIS G, SLEIGHT P, ANDERSON C ON BEHALF OF ONTARGET INVESTIGATORS: Telmisartan, ramipril, or both in patients at high risk for vascular events. $N$ Engl J Med 358: 1547-1559, $2008 \mathrm{~b}$.

YUSUF S, WITTES J: Interpreting geographic variations in results of randomized, controlled trials. $N$ Engl J Med 375 : 2263-2271, 2016.

ZIFF OJ, COVIC A, GOLDSMITH D: Calibrating the impact of dual RAAS blockade on the heart and the kidney balancing risks and benefits. Int J Clin Pract 70: 537-553, 2016.

ZOJA C, ABBATE M, REMUZZI G: Progression of chronic kidney disease: insight from animal models. Curr Opin Nephrol Hypertens 15: 250-257, 2006.

ZOJA C, CORNA D, CAMOZZI D, CATTANEO D, ROTTOLI D, BATANI C, ZANCHI C, ABBATE M, REMUZII $\mathrm{G}$ : How to fully protect the kidney in a severe model of progressive nephropathy: a multidrug approach. $J A m$ Soc Nephrol 13: 2898-2908, 2002. 